\title{
The enigmatic Marmorkrebs (marbled crayfish) is the parthenogenetic form of Procambarus fallax (Hagen, 1870)
}

\author{
Peer Martin ${ }^{1}$, Nathan J. Dorn², Tadashi Kawai ${ }^{3}$, Craig van der Heiden², Gerhard Scholtz ${ }^{1,4}$ \\ ${ }^{1}$ Institut für Biologie/Vergleichende Zoologie, Humboldt-Universität zu Berlin, Berlin, Germany \\ ${ }^{2}$ Department of Biological Sciences, Florida Atlantic University, Davie, FL, USA \\ ${ }^{3}$ Hokkaido Wakkanai Fisheries Experimental Station, Hokkaido, Japan \\ ${ }^{4}$ E-mail: gerhard.scholtz@rz.hu-berlin.de
}

Key words: 12S rRNA, annulus ventralis, COI, DNA barcoding, species concept, thelytoky

\begin{abstract}
A mysterious parthenogenetic cambarid crayfish (the Marmorkrebs) has been spreading across the globe for the past decade. We compare this crayfish directly to two other cambarids, Procambarus fallax and P. alleni, that have been suggested to be related or even identical to the Marmorkrebs. Using external morphology and sequences of two mitochondrial genes we show clear correspondences between Marmorkrebs and P. fallax, a species found natively throughout peninsular Florida, USA. Based on these congruent results we suggest that the Marmorkrebs is the parthenogenetic form of P. fallax. This finding has potential evolutionary and ecological implications at several levels. The Marmorkrebs might be a type of geographical parthenogenesis, but a natural population in the wild is so far unknown. Furthermore, challenges arise in regard to the respective species status of the Marmorkrebs. Taxonomically we suggest that the Marmorkrebs is treated as 'parthenogenetic form' of $P$. fallax. Last but not least, the identity of this animal and its ecology has an impact for considering potential spread and effects of this species across the globe.
\end{abstract}

\section{Contents}

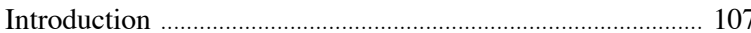

Material and methods ............................................................... 108

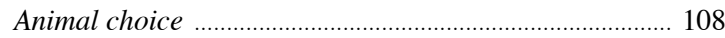

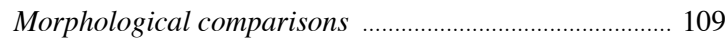

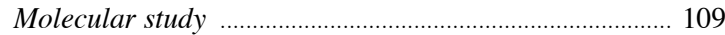

Results ............................................................................... 110

Morphological comparisons reveal detailed similarities

between Procambarus fallax and Marmorkrebs ............... 110

Molecular analysis shows a high degree of

DNA sequence congruence between Procambarus fallax

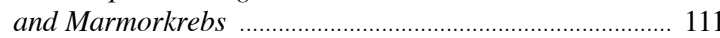

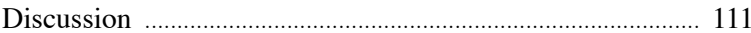

The relationship of the Marmorkrebs to

Procambarus fallax ........................................................... 111

The origin of parthenogenesis in crayfish ....................... 114

Ecological implications ……………………………......... 115

Acknowledgements ............................................................... 115

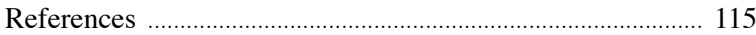

\section{Introduction}

In 2003 Scholtz et al. reported that an unidentified crayfish in Germany was reproducing parthenogenetically in an aquarium. This was the first record of a parthenogenetic decapod crustacean, and while its identity was unknown it was dubbed Marmorkrebs (marbled crayfish) for its marbled carapace.

Based on molecular evidence, on morphological characters, and on characteristics of the postembryonic development, it was clear that the Marmorkrebs belongs to the large group of the North American Cambaridae (Scholtz et al., 2003; Vogt et al., 2004). Unfortunately, however, a precise determination of the position of the Marmorkrebs within the cambarids has not been possible so far. Because of its thelytokous parthenogenesis, only females are known to date. Thus, all existing keys to this group, based on characters of the male gonopods (e.g. Hobbs, 1972, 1989) cannot be used.

Due to its very similar coloration and general appearance Procambarus fallax (Hagen, 1870) (Fig. 1) has been included in the initial molecular study on Marmorkrebs' phylogenetic relationships (Scholtz et al., 2003). Indeed, this analysis based on mitochondrial data has resolved the Marmorkrebs as the closest relative of Procambarus fallax (Scholtz et al., 2003). However, the putative identity between P. fallax and Marmorkrebs has not been tested. Subsequently, several authors have considered the Marmorkrebs to be a parthenogenetic Procambarus alleni (Faxon, 1884) (see Vogt, 2008). This is an unsatisfying situation since the Marmorkrebs is currently being established as a laboratory model organism and over the past 7 years research and publications on the development of female clones of Marmorkrebs have been growing (e.g. Vogt et al., 2004; Seitz et al., 2005; Alwes and Scholtz, 2006; 
Martin et al., 2007; Vogt, 2008; Vogt et al., 2008). Meanwhile the Marmorkrebs has been spreading over the globe, ostensibly via the aquarium trade and specimens have been found in the wild in Germany, the Netherlands, Italy, Japan, and Madagascar (e.g. Holdich et al., 2009; Jones et al., 2009; Kawai et al., 2009; Martin et al., 2010; Kawai and Takahata, 2010) (Table 1). The purpose of this article is to definitively identify the species affinity of the Marmorkrebs through comparative morphological and genetic analyses.

Table 1. Countries where Marmorkrebs (parthenogenetic P. fallax) are reported to be found in the wild.

\begin{tabular}{ll}
\hline country & citations \\
\hline Germany & $\begin{array}{l}\text { Marten } \text { et al., 2004; Souty-Grosset } \text { et al., } \\
\text { 2006; Martin } \text { et al., 2010 }\end{array}$ \\
Ketherlands & $\begin{array}{l}\text { Koese and Vletter, 2008; Souty-Grosset } \text { et } \\
\text { al., 2006 }\end{array}$ \\
Italy & Marzano et al., 2009 \\
Madagascar & Jones et al., 2009; Kawai et al., 2009 \\
Japan & Kawai and Takahata, 2010 \\
\hline
\end{tabular}

\section{Material and methods}

\section{Animal choice}

Based on the studies of Scholtz et al. (2003) and Vogt et al. (2004) it is clear that the Marmorkrebs is a member of the North American Cambaridae. This group consists of about 400 species showing a great diversity of forms and lifestyles (e.g. Lukhaup, 2003). This makes the determination of the closest relative or even the species of origin of the Marmorkrebs comparable to a search for a needle in a haystack. However, the study of Seitz et al. (2005) indicates that the Marmorkrebs appears to be adapted to a relatively warm environment which excludes species occurring in the northern parts of the United States or in Canada. Furthermore, crayfish species with a notably similar appearance to the Marmorkrebs are not so common. For instance, according to Hobbs $(1942,1981)$ none of the other Procambarus crayfish forms in the south-eastern region of the United States area has a similar morphology. This is the reason why the two species from
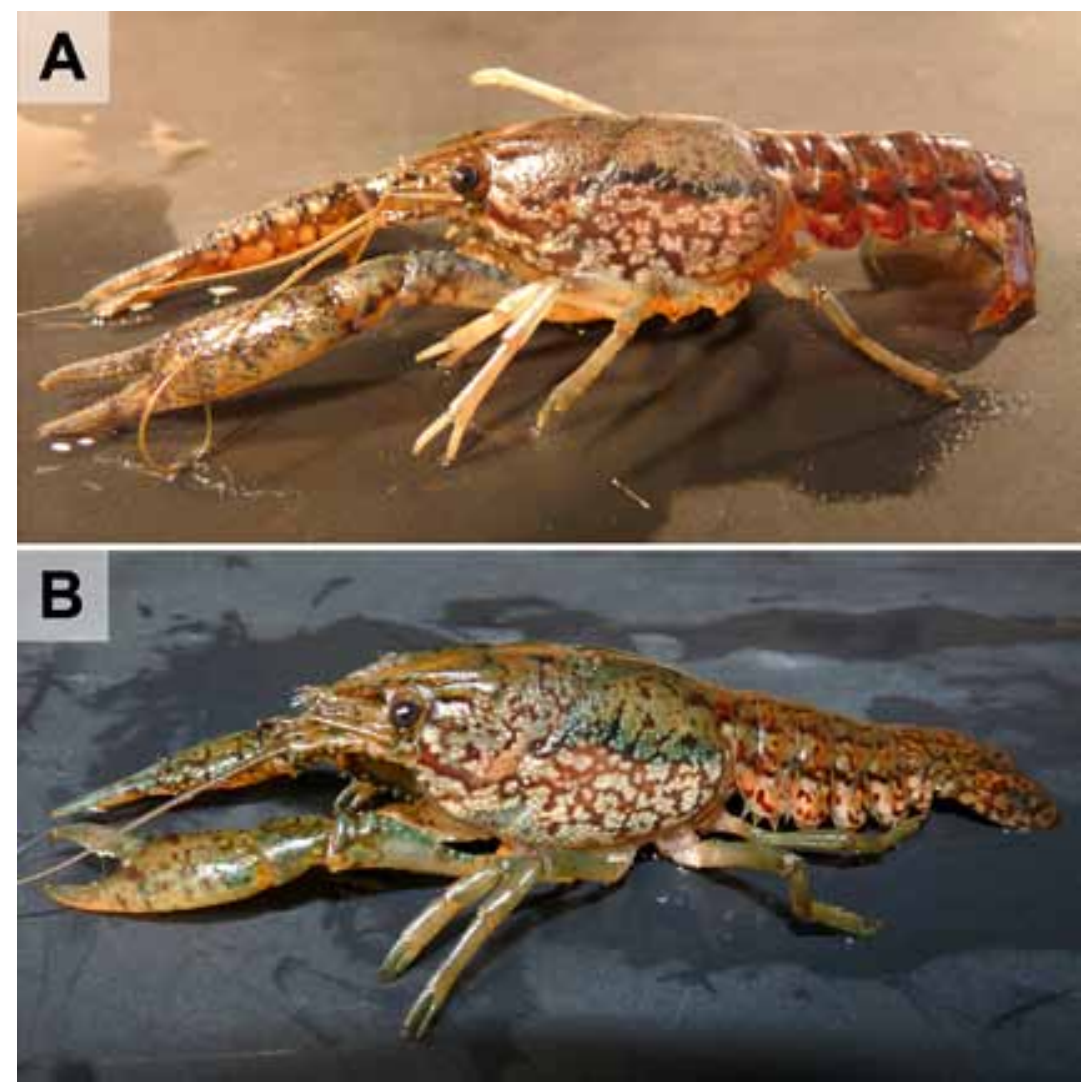

Fig. 1. Similar appearance of A) Procambarus fallax (male) from the aquarium trade and B) Marmorkrebs (female) from HU-stock. 
Florida, Procambarus fallax (Slough Crayfish) and $P$. alleni (Everglade Crayfish) have been suggested to be either closely related or even identical to the latter (Scholtz et al., 2003; Vogt, 2008; Jones et al., 2008; Kawai et al., 2009). Here we follow and test these previous suggestions.

\section{Morphological comparisons}

Procambarus fallax and P. alleni occur in the southeast of the USA (Hobbs, 1981, 1989; Lukhaup, 2003). As part of past and ongoing population studies in south Florida both species are found in a diversity of habitats including forested and open wetlands, ponds, and ditches (Hendrix and Loftus, 2000; Dorn and Trexler, 2007; Dorn and Volin, 2009).

While the first two pairs of male pleopods, the gonopods are generally considered necessary for identifying crayfish (e.g. Hobbs, 1972, 1981, 1989), the ecological studies in south Florida require the identification of preserved specimens including males and females. A key feature for the differentiation of females of these two species even at small $(<10 \mathrm{~mm}$ carapace length, CL) sizes is the morphology of the sperm receptacle, the annulus ventralis (Dorn and Trexler, 2007). For this study the annulus ventralis of preserved P.fallax $(\mathrm{n}=12)$ and P. alleni $(\mathrm{n}=10)$ from Florida was compared with that of preserved Marmorkrebs ( $\mathrm{n}>18$ of specimens from Berlin).

There are important coloration differences in live P. fallax and P. alleni that were noted by Hendrix and Loftus (2000). Accordingly, in this study we compare the overall coloration patterns and some more detailed aspects between P. fallax, P. alleni, from Florida and Marmorkrebs specimens from the Humboldt-Universität zu Berlin and from the aquarium trade in Japan based on living individuals and on the images published in the scientific literature (e.g. Scholtz et al., 2003, Seitz et al., 2005, Kawai et al., 2009) and online (various sites).

\section{Molecular study}

For our molecular genetic analysis we used partial sequences of the mitochondrial protein coding cytochrome oxidase subunit I gene (COI) and the mitochondrial 12S ribosomal RNA gene, which are well established markers for comparisons at the species level including freshwater crayfish (e.g. Hebert et al., 2003; Munasinghe et al., 2004; Sinclair et al., 2004; BalitzkiKorte et al., 2005; Schubart and Huber, 2006; Chu et al., 2006; Braband et al., 2007; Costa et al., 2007; Ferri et al., 2009; Toon et al., 2009; Filipová et al., 2010). Total DNA was extracted by using a DNA extraction kit (DNeasy Blood and Tissue Kit, Qiagen) from muscle tissue of walking legs of several specimens of each, $P$. fallax collected from different areas of the Water Conservation Areas of the Everglades (South Florida, USA.) and P. alleni sampled from wetlands near Tampa Bay (West Florida) and from areas of the Big Cypress National Preserve (South Florida), respectively (Table 2). For amplifying the COI fragment we used the universal primer pair LCO1490/HCO2198 designed by Folmer $e t$ al. (1994) following the slightly modified protocol described by the same authors. PCR was performed in a final volume of $25 \mu \mathrm{l}$ with 10 to $100 \mathrm{ng}$ of total DNA,

\begin{tabular}{llllll}
\hline specimen & sex & origin & species & \multicolumn{2}{l}{ accession number } \\
& & & & COI & 12S \\
\hline mc-HU & female & HU stock & Marmorkrebs & HM358010 & HM358014 \\
mc-Sax & female & Saxony & Marmorkrebs & HM358011 & HM358015 \\
pal-1 & female & Florida & P. alleni & HQ171449 & HQ171460 \\
pal-3 & female & Florida & P.alleni & HQ171451 & HQ171461 \\
pal-4 & female & Florida & P. alleni & HQ171452 & HQ171462 \\
pal-10 & male & Florida & P. alleni & HQ171450 & HQ171463 \\
pal-HU & male & Aquarium trade & P.alleni & HM358013 & HM358017 \\
pfx-5 & female & Florida & P.fallax & HQ171455 & HQ171464 \\
pfx-6 & female & Florida & P.fallax & HQ171456 & HQ171465 \\
pfx-7 & female & Florida & P.fallax & HQ171457 & HQ171466 \\
pfx-8 & male & Florida & P.fallax & HQ171458 & HQ171467 \\
pfx-9 & female & Florida & P.fallax & HQ171459 & HQ171468 \\
pfx-11 & female & Florida & P.fallax & HQ171453 & HQ171469 \\
pfx-12 & female & Florida & P.fallax & HQ171454 & HQ171470 \\
pfx-HU & male & Aquarium trade & P.fallax & HM358012 & HM358016 \\
\hline
\end{tabular}

Table 2. Details of the analysed specimens and their GenBank ${ }^{\circledR}$ accession numbers of the COI and $12 \mathrm{~S}$ sequences. 


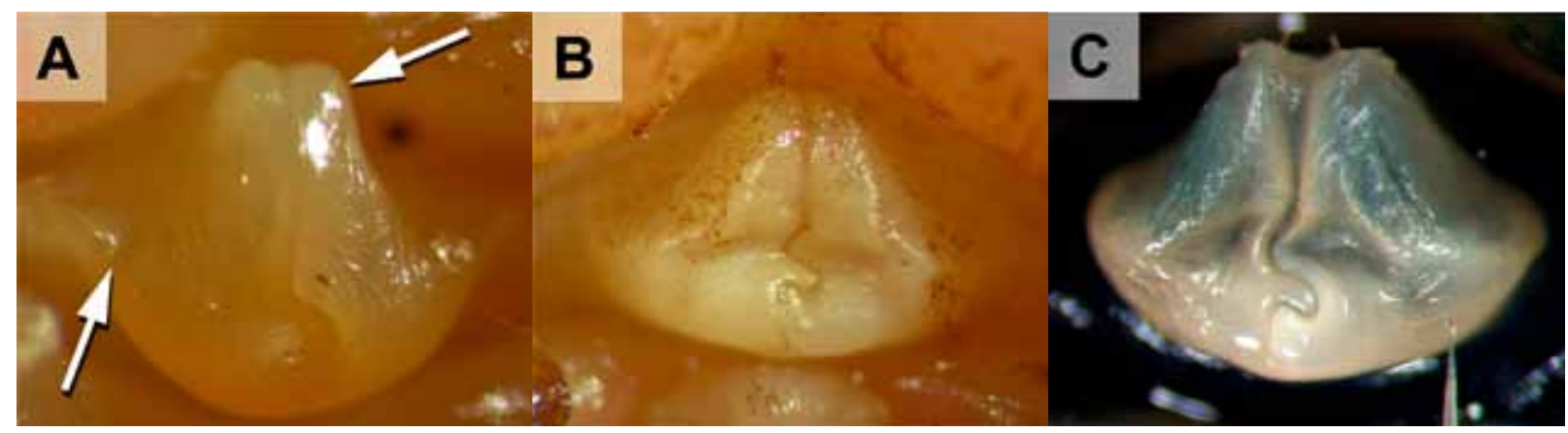

Fig. 2. Annulus ventralis of A) Procambarus alleni, B) Procambarus fallax from south Florida wetlands, and C) Marmorkrebs from Germany. All crayfish were $>28 \mathrm{~mm}$ carapace length ( $>20 \mathrm{~mm}$ post orbital carapace length). The arrows point to the differences between the annulus ventralis of $P$. alleni with the peaked anterior portion and the scooped lateral wings and that of $P$. fallax/Marmorkrebs which lack these characteristics.

$1 \times\left(\mathrm{NH}_{4}\right) 2 \mathrm{SO}_{4}$ buffer, $3 \mathrm{mM} \mathrm{MgCl} 2,0.2 \mathrm{mM}$ of each $\mathrm{dNTP}, 0.2 \mu \mathrm{M}$ of each forward and reverse primer, and $0.6 \mathrm{U}$ Taq DNA polymerase. Amplification commenced at $94^{\circ} \mathrm{C}$ for 2 min followed by five cycles of $1 \mathrm{~min}$ at $96^{\circ} \mathrm{C}, 1.5 \mathrm{~min}$ at $45^{\circ} \mathrm{C}$ and $1.5 \mathrm{~min}$ at $72^{\circ} \mathrm{C}$, afterwards succeeded by 35 cycles of $93^{\circ} \mathrm{C}$ for $1 \mathrm{~min}, 50^{\circ} \mathrm{C}$ for 1.5 $\min , 72^{\circ} \mathrm{C}$ for $1.5 \mathrm{~min}$, and finished finally with a 5 -min extension at $72^{\circ} \mathrm{C} .12 \mathrm{~S}$ rRNA fragment was amplified using the primers CF12FOR (5'-AMATGARAGCGACGGGCGAT) and CF12REV (5'-AWCAAYTAGGATTAGATACC) designed by Braband et al. (2007) according to a standard PCR protocol with 40 cycles of $94^{\circ} \mathrm{C}$ for $30 \mathrm{~s}, 40^{\circ} \mathrm{C}$ for $30 \mathrm{~s}$, and $72^{\circ} \mathrm{C}$ for $40 \mathrm{~s}$, and with a final extension of $72^{\circ} \mathrm{C}$ for 5 minutes. All PCR products were purified by the MinElute ${ }^{\circledast}$ PCR Purification Kit (Qiagen) and sense and antisense strand of the fragments were sequenced by the sequencing service company LGC Genomics Berlin, Germany. For the phylogenetic analysis, the produced sequences were compared with a data set obtained from another study (Martin et al., 2010) of two Marmorkrebs specimens from our laboratory culture (mc-HU) and from Saxony (south-east Germany; mc-Sax) and one male of P.fallax (pfx-HU) and $P$. alleni (pal-HU) from the aquarium trade. For tree reconstruction further data of other Procambarus species and the cambarid Orconectes limosus (Rafinesque, 1817) were added from GenBank ${ }^{\circledR}$ (Accession numbers see Fig. 4). The COI and the $12 \mathrm{~S}$ datasets were aligned using the ClustalW Multiple alignment application (Thompson et al., 1994) integrated in the program BioEdit version 7.0.9.0. for Windows (Ibis Biosciences, USA; Hall 1999) and subsequently pruned by using the program Gblocks $0.91 \mathrm{~b}$ (Castresana, 2000) with the following parameters: minimum number of sequences for a conserved position (COI/12S) 10/11, minimum number of sequences for a flanking position (COI/12S) 16/18, maximum number of contiguous non conserved positions (COI/12S) 4/4, minimum length of a block (COI/12S) 10/10, allowed gap positions (COI/12S) none/none. In addition, the COI alignment was carefully checked as recommended by Buhay (2009) to avoid data corruption through pseudogenes such as 'COI-like' nuclear mitochondrial DNA (numt). A maximum-likelihood (ML) tree consisting of the sequenced specimens and additional species was computed from a combination of both the COI and $12 \mathrm{~S}$ sequences with the program TREEFINDER (Jobb, G. TREEFINDER, version Oct. 2008, Munich, Germany. Distributed by the author at www.treefinder.de) using the substitution models $\mathrm{J} 1+\mathrm{G}(\mathrm{TA}=\mathrm{TG}$ and $\mathrm{CA}=\mathrm{CG}$; complexity $3+3$ ) for $\mathrm{COI}$ partition and the $\mathrm{HYK}+\mathrm{G}$ for $12 \mathrm{~S}$ partition estimated by the program-internal model proposer based on the Akaike Information Criterion (AICc), with five rates categories, and with 1000 replicates for bootstrap analysis. The tree was rooted at $\mathrm{Or}$ conectes limosus. Pairwise nucleotid divergences between P. fallax, P. alleni and Marmorkrebs were calculated separately for $\mathrm{COI}$ and $12 \mathrm{~S}$ with the program MEGA4.0.2 by using the Tamura-Nei (TN) model (Tamura et al., 2007) estimated by the TREEFINDER model proposer.

\section{Results}

Morphological comparisons reveal detailed similarities between Procambarus fallax and Marmorkrebs

Concerning morphological characters the Marmorkrebs identifies closely with $P$. fallax and is quite distinct 
from P. alleni (Figs 2-3). The Marmorkrebs annulus ventralis lacks the characteristic scooped 'wings' on the lateral parts and the anterior portion is not peaked like the annulus ventralis of P. alleni (Fig. 2A vs. B-C). In contrast, the Marmorkrebs annulus ventralis closely resembles the flatter, bell-shaped annulus ventralis of P.fallax (see also Hobbs, 1942; Kawai et al., 2009) (Fig. 2). Furthermore, the Marmorkrebs annulus ventralis does not closely resemble that of any other North American members of the genus Procambarus (Hobbs, 1989). The overall coloration pattern of P. fallax (Fig. 3 ), including a 'marbled' carapace and lateral dark stripes, is consistent with the coloration of Marmorkrebs from the Berlin laboratory culture, in published photos (Scholtz et al., 2003; Seitz et al., 2005; Vogt et al., 2008; Kawai et al., 2009), and with those on the internet. The dark lateral horizontal stripes through the cephalothorax and abdomen on P. fallax (Fig. 3B) can vary in intensity between individuals (or populations), but a distinct stripe is a good indication that the crayfish is P. fallax (Fig. 3B) rather than P.alleni (Fig. 3A). Specimens of Procambarus alleni have conspicuous dark spots ventral to the bases of the eye stalks and anterior to the oral cavity (Fig. 3A) while those of P. fallax do not (Fig. 3B). This was first pointed out by Hendrix and Loftus (2000) and after seeing thousands of individuals of these species we can further attest to the uniformity of this difference in south Florida (N. Dorn, pers. obs.). All the Marmorkrebs individuals studied in the laboratory culture in Berlin lack these conspicuous spots (Fig. 3C). The absence of these spots can also be clearly seen in Kawai et al. (2009) from Marmorkrebs from the Japanese aquarium trade (Fig. 3D).

Molecular analysis shows a high degree of DNA sequence correspondence between Procambarus fallax and Marmorkrebs

The molecular analysis shows distances of the COI sequences (total length 675 base pairs) between P. alleni and P. fallax ranging from 6.40 to $7.24 \%$ (mean $6.88 \pm$ $1.01 \%$ ), between P. alleni and Marmorkrebs from 6.75 to $7.24 \%$ (mean $6.88 \pm 1.05 \%$ ), and between P. fallax and Marmorkrebs from 0.60 to 0.75 (mean $0.67 \pm$ $0.24 \%$ ). Within the species, the values are $0.00-1.36 \%$ (mean $0.79 \pm 0.25 \%$ ) in P. alleni and $0.00-1.05 \%$ (mean $0.57 \pm 0.19 \%$ ) in $P$. fallax. The $12 \mathrm{~S}$ sequences ( 381 base pairs) of $P$. fallax and Marmorkrebs are identical. This is also true for the $P$. alleni specimens, where uniform sequences are found except in specimen pal-10, which shows a single substitution. The distance between the $P$. fallax / Marmorkrebs complex and the $P$. alleni population ranges from 2.95 to $3.27 \%$ (mean $3.02 \pm 0.92 \%$ ). The two Marmorkrebs specimens are identical in the $\mathrm{COI}$ and $12 \mathrm{~S}$ sequences over a total length of 1057 base pairs (see also Martin et al., 2010).

For tree reconstruction, a total data set consisting of the combined $\mathrm{COI}$ and $12 \mathrm{~S}$ sequences of the specimens listed in Table 2 and a selection of several species from GenBank ${ }^{\circledR}$ of 927 nucleotides was available after pruning the DNA alignments with the program Gblocks $0.91 \mathrm{~b}$. The resulting tree shows that the two Marmorkrebs specimens nest clearly within the P. fallax representatives (Fig. 4). The same result was obtained if each gene alone was used for tree reconstruction (not shown).

\section{Discussion}

The relationship of the Marmorkrebs to Procambarus fallax

Our comparison of morphological aspects and our analysis of molecular sequence data show a congruent result revealing the close affinities between Marmorkrebs and Procambarus fallax.

The shape of the annulus ventralis is clearly identical between P. fallax and Marmorkrebs to the exclusion of $P$. alleni and other cambarid crayfish species (Hobbs, 1942). The body coloration, despite some variability (see Hobbs, 1989), points strongly to the same direction. Pigmentation can be affected by coloration of the background environment (Thacker et $a l ., 1993)$ and we observe differences in the size of the marbled spots and darkness of pigments in wild caught animals in Florida wetlands and between individuals of Marmorkrebs (Vogt et al., 2008; Martin et al., 2010). The close resemblance of P. fallax and the Marmorkrebs speaks against the possibility that the latter originated from a hybridisation event (see below).

Furthermore, the analysis of the two mitochondrial genes convincingly supports the assumption of a close relationship between Marmorkrebs and P. fallax. Regarding the $12 \mathrm{~S}$ marker, the sequences of both groups are identical. In contrast, clear differences occur between them and $P$. alleni. In comparison to the $12 \mathrm{~S}$ gene, divergences exist in the COI data within P.fallax and $P$. alleni, but these values were almost ten times lower than the average value between both species. Differences are also found between Marmorkrebs and 


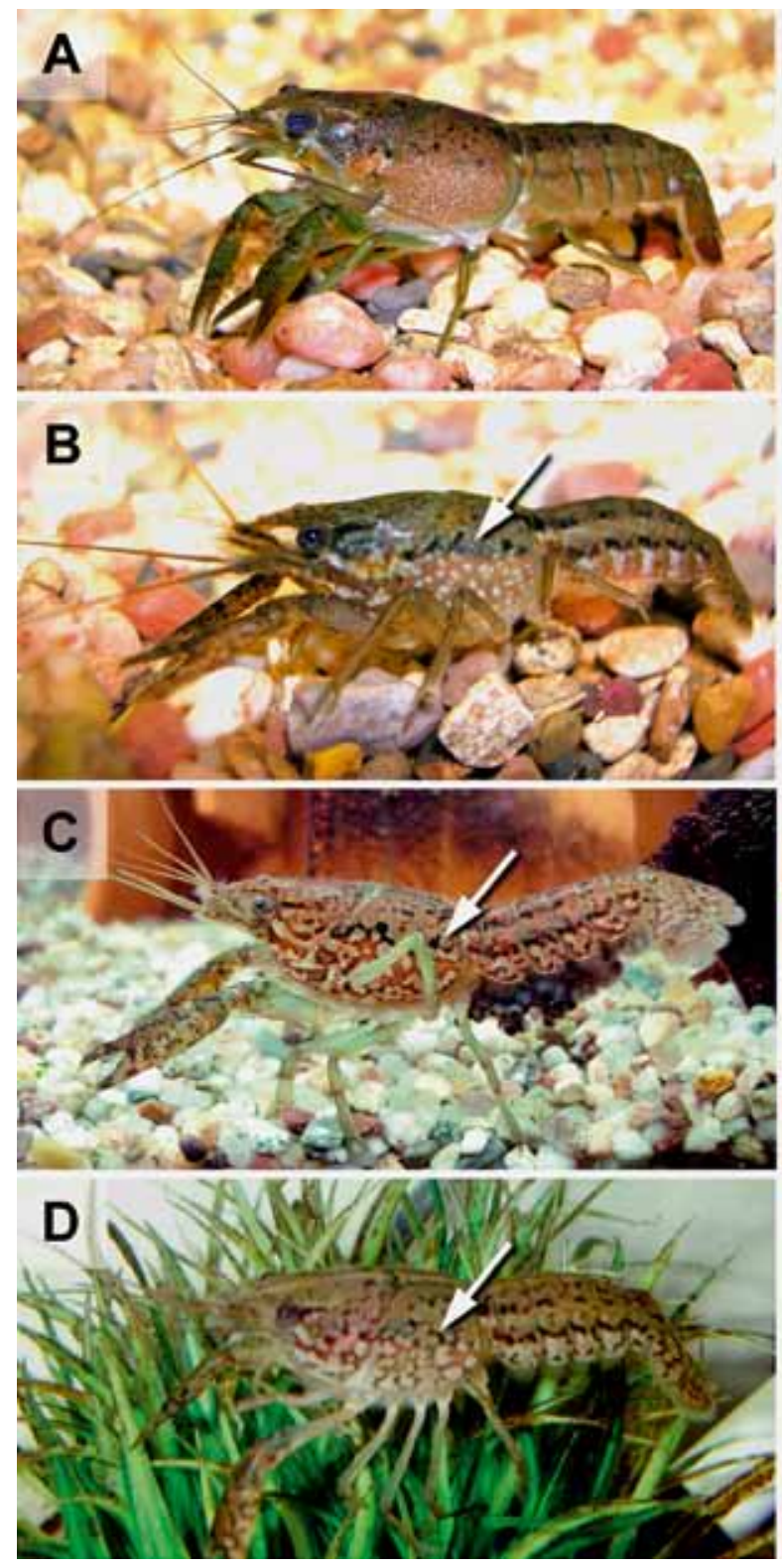

$P$. fallax. However, the values remain in the range of the calculated distances within P.fallax. Furthermore, the divergence of Marmorkrebs to $P$. alleni is on average ten times higher, and thus corresponding to that between $P$. fallax and $P$. alleni. All this implies that the Marmorkrebs shows indeed very close affinities to $P$. fallax.

The result of the divergence analysis coincides well to the reconstructed ML tree, which shows that the two Marmorkrebs specimens are deeply nested within the individuals of $P$. fallax. Furthermore, the $P$. fallax/

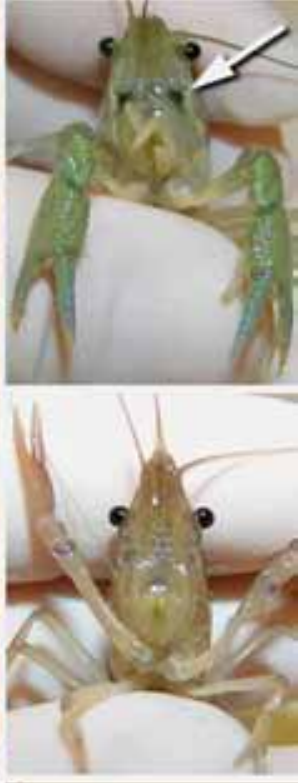

Fig. 3. Photographs of live A) Procambarus alleni and B) Procambarus fallax from south Florida, USA and C) Marmorkrebs from the lab cultures in Germany and the aquarium trade in Japan D). In every case the lateral overall view (left) and the facial ventral view (right) is shown. The arrows in the left pictures mark the dark lateral horizontal stripes through the cephalothorax and abdomen in P. fallax and Marmorkrebs (compare with Fig. 1). The arrow in the top right picture points at the facial dark spots characteristic for P. alleni.
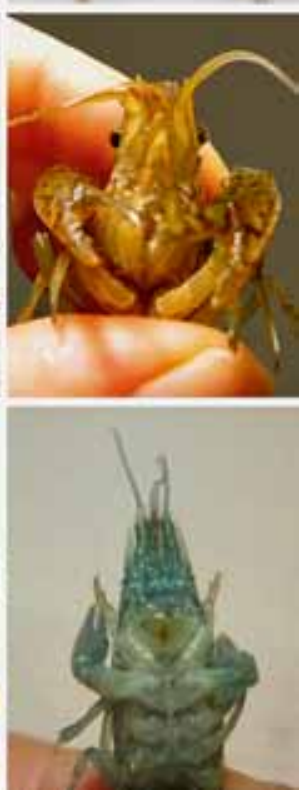

Marmorkrebs branch is strongly supported by the bootstrap value of $100 \%$, which is another indication for the very close affinities or even identity of Marmorkrebs and P. fallax.

Taken together, all this reveals that the Marmorkrebs is a parthenogenetic form of $P$. fallax.

While our conclusion that Marmorkrebs is a parthenogenetic $P$. fallax agrees with tentative suggestions of Scholtz et al. (2003) and Kawai et al. (2009) this is the first direct morphological comparison between each species and Marmorkrebs and it is the first genetic 


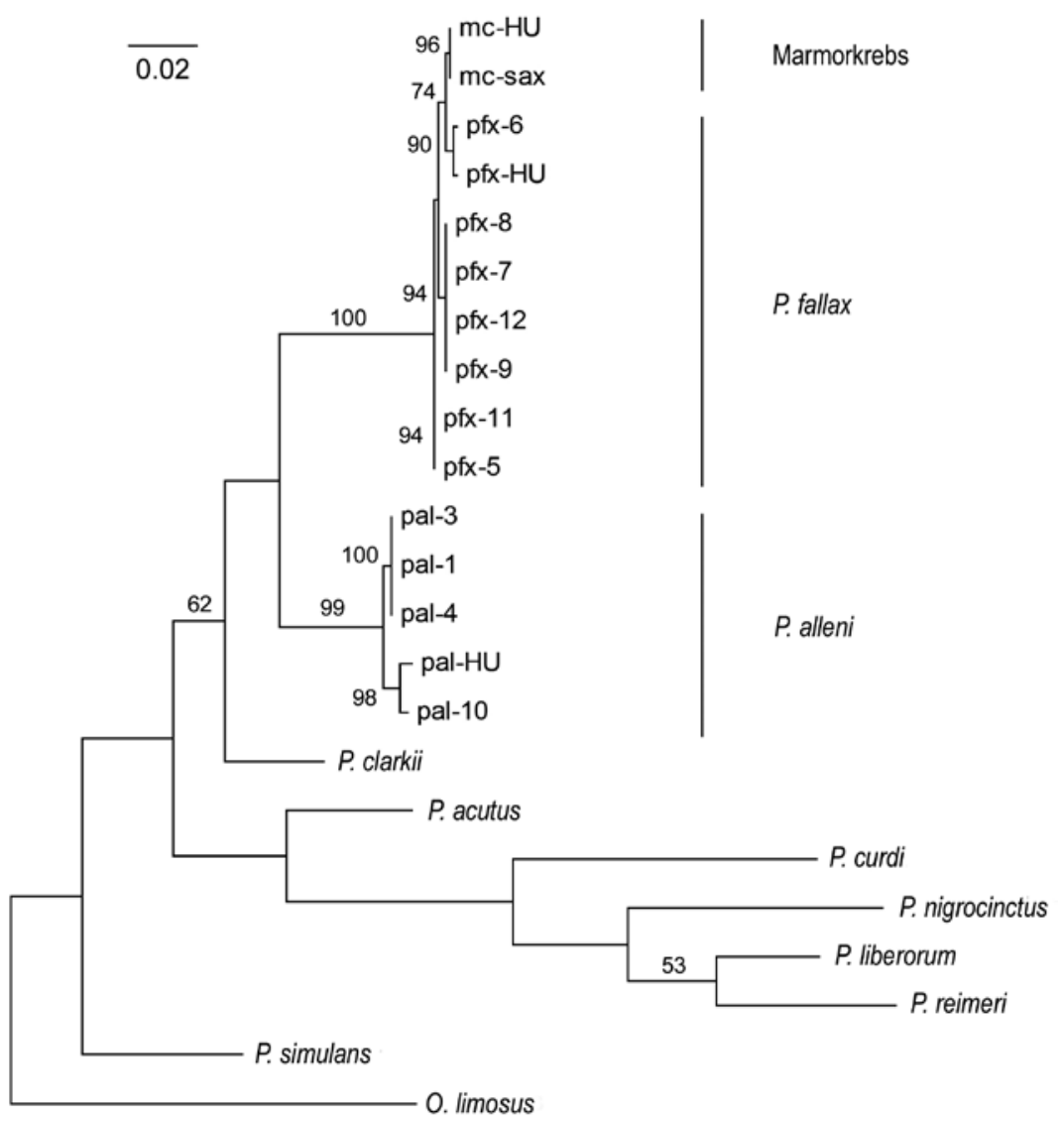

Fig. 4. Maximum-likelihood analysis of Marmorkrebs, several Procambarus species, and Orconectes limosus as outgroup. The tree was estimated from combined nucleotide sequence data sets of $\mathrm{COI}$ and $12 \mathrm{~S}$ mitochondrial genes calculated under the $\mathrm{J} 1+\mathrm{G}$ and the $\mathrm{HYK}+\mathrm{G}$ model, respectively, with five rates categories. Numbers above branches are values in percent obtained from the bootstrap analysis of 1,000 replicates (bootstrap support values lower than $50 \%$ are not shown). The scale bar indicates the evolutionary distances in substitutions per site. Accession numbers of the used sequences from the $\mathrm{GenBank}^{\odot}$ are (COI /12S) $(\div=$ sequence not available $): P$. clarkii AY701195/EF 012280, P. acutus AF474366/FJ619794, P. curdi Reimer, $1975 \div / \mathrm{EF012281,} \mathrm{P.} \mathrm{liberorum} \mathrm{Fitz-}$ patrick, $1978 \div / \mathrm{EF} 012311$, P. nigrocinctus Hobbs, Jr., $1990 \div / \mathrm{EF} 012282, P$. reimeri Hobbs, $1979 \div / \mathrm{EF} 012283, P$. simulans (Faxon, 1884) EU583575/ $\div, O$. limosus AY701199/AY151531. study including a comparison with both species. All molecular analyses performed prior to this study had confirmed that Marmorkrebs is a cambarid and that it is neither closely related to P. clarkii (Girard, 1852) (Scholtz et al., 2003) nor to P. acutus (Girard, 1852) (Marzano et al., 2009). In contrast to our conclusion, Vogt (2008) and Jones et al. (2009) suggested that the Marmorkrebs is probably P. alleni based on molecular analyses, but their studies did not include $P$. fallax.

Marmorkrebs is only known from aquaria and from secondary releases to the wild in various countries (Martin et al., 2010). Other crustaceans, like the widespread European terrestrial isopod species Trichoniscus pusillus Brandt, 1833 exhibit both biparental and parthenogenetic unisexual populations in a patchwork distribution (Vandel, 1928, 1938). Differences in reproductive mode of the populations may be related to micro-habitat conditions (Fussey, 1984). While we do not see a patchwork distribution of uni- and bi-sexual populations of $P$. fallax, indeed most populations have a close to a 1:1 sex ratio (N. Dorn, unpublished data); parthenogenetic abilities among $P$. fallax females would not require the existence of completely unisexual populations.

Our molecular data reveal that the Marmorkrebs origi nated from within the population of Procambarus fallax. This raises the question of its taxonomic treatment, i.e. should it be considered a new species, or a subspecies, or a form of $P$. fallax? It is evident that this is not trivial because it touches the general problem of species concepts (see Sudhaus and Rehfeld, 1992; Wheeler and Meier, 2000). For instance, according to the biological species concept, a species is defined by its capacity of sexual reproduction in combination with genetic isolation to other species. A biological species is thus a reproductively cohesive assemblage of populations (Mayr, 2000). Accordingly, parthenogenetic lineages are no longer part of the original species since they are genetically isolated from its species of origin. But by Mayr's own admission the biological species concept does not apply to asexual organisms (Mayr, 2000) and is therefore unhelpful in dealing with the Marmorkrebs. According to the Hennigian species concept (Meier 
and Willmann, 2000), the switch of a subpopulation of a species to uniparental reproduction can be seen as a sort of speciation event resulting in the occurrence of two daughter lineages: a new species and an agamotaxon (Meier and Willmann, 2000). Due to these conceptual difficulties, there are numerous contradictory suggestions how to treat parthenogenetic lineages taxonomically (e.g. Enghoff, 1976; Suomalainen et al., 1987; Frost and Wright, 1988; Sudhaus and Rehfeld, 1992).

There are a number of aspects that speak against the establishment of a new species for the Marmorkrebs. First, we do not know whether the Marmorkrebs had a single origin or whether it arose (arises) repeatedly from P. fallax. Second, the Marmorkrebs is morphologically not distinct from $P$. fallax. Third, since the natural range of Marmorkrebs is unknown to date we cannot argue with specific ecological requirements of the Marmorkrebs which would allow the application of the ecological species concept (e.g. Van Valen, 1976; Sudhaus and Rehfeld, 1992). In particular, the latter point argues also against the consideration of the Marmorkrebs as a subspecies of P. fallax.

However, a scientific name for the Marmorkrebs is strongly demanded. Thus, we have decided to take up the recommendations of Enghoff (1976) and Suomalainen et al. (1987) who propose that a parthenogenetic lineage which derived from a bisexual species should neither be regarded as a separate species nor as a subspecies but as a 'parthenogenetic form' of the bisexual species. Hence, we recommend 'Procambarus fallax (Hagen, 1870) f. virginalis' as a proper name for articles dealing with Marmorkrebs. Although 'forma' is not accepted by the International Code of Zoological Nomenclature (ICZN) (1999) it appears appropriate for the time being. If additional data should clarify some of the problematic issues (e.g. confirmation of a single origin and/or the detection of regional populations of the Marmorkrebs in the wild) it should be easy to establish a new species using 'virginalis' as epithet.

\section{The origin of parthenogenesis in crayfish}

It is interesting to consider the mode of the switch to obligate parthenogenesis in the Marmorkrebs (Suomalainen et al., 1987; Normark, 2003; Simon et al., 2003; Kearney, 2005; Lundmark and Saura, 2006). However, the occurrence of a thelytokous lineage from P. fallax is difficult to explain because Marmorkrebs reproduce apomictically (i.e. the eggs do not undergo meiosis; Martin et al., 2007). Little is known about the origin of apomictic parthenogenesis from a bisexual ancestor (White, 1973; Suomalainen et al., 1987; Normark, 2003; Schwander et al., 2009). One possible explanation could be the occurrence of the so called tychoparthenogenesis. This is a relatively widespread type of parthenogenesis in sexual invertebrates in which females show a certain capability to parthenogenetic reproduction (White, 1973; Suomalainen et al., 1987). Tychoparthenogenesis might be advantageous in an environment such as the Everglades or other wetlands in south Florida with considerable inter- and intra-annual variation in water depths. Here a genotype capable of asexual reproduction stands a better chance of locally persisting through a series of years of unfavourable conditions when overall densities are low and sexual reproduction is unlikely (Ball, 2002; Sekiné and Tojo, 2010). However, almost all tychoparthenogens known to date reproduce automictically, e.g. by meiotic parthenogenesis, (White, 1973; Suomalainen et al., 1987; Ball, 2002; Schwander et al., 2009) and hence it is doubtful that thelytoky in the apomictic Marmorkrebs originated this way. In addition, if such parthenogenetic capability were common in decapods, more thelytokous species than just the Marmorkrebs have to be expected. According to Yue et al. (2008) some of the introduced Chinese populations of the American cambarid freshwater crayfish Procambarus clarkii demonstrate a pattern of molecular markers (microsatellites) that suggests the occurrence of genetically uniform populations. However, some doubts remain whether this is indeed an indirect evidence for an apomictic parthenogenetic reproduction. The occurrence of identical genotypes with a high degree of heterozygosity is not necessarily caused by parthenogenesis. It can also arise, according to Mendel's law, in the $F_{1}$ generation when the parents are homozygous in genes with different alleles. This is often found in populations with inbreeding effects caused by introduction of only few specimens.

A further possibility for the switch from sexual to obligate parthenogenetic reproduction can be an infection with the intracellular bacterium Wolbachia pipientis Hertig, 1936 (Stouthamer et al., 1999) or by mating of parthenogenetically produced males with sexual females (contagious origin; Simon et al., 2003). However, these two origins are unlikely because Wolbachia-like bacteria could not be detected in Marmorkrebs and parthenogenetically produced males are not known in Astacida (Vogt et al., 2004).

Another possible route towards obligate parthenogenetic lineages is the hybridisation of two closely 
related and sympatric cambarid species such as $P$. fallax and $P$. alleni. Since mitochondria are almost exclusively inherited from the maternal lineage (Perry et al., 2001a), based on mitochondrial genes alone we cannot exclude the possibility that the Marmorkrebs and its parthenogenesis are the product of a hybridization event. However, our comparative morphological results contradict this possibility. The morphology of the Marmorkrebs presents no blend of two species but clearly resembles that of $P$. fallax alone. Hybrids, even between closely related cambarid species, are clearly recognizable because of their intermediate morphological characters as shown in Orconectes by Capelli and Capelli (1980) and Perry et al. (2001b). Furthermore, the experimental hybridisation of the two Australian freshwater crayfish species, Cherax rotundus Clark, 1941 and C. albidus Clark, 1936 did not result in parthenogenesis (Lawrence and Morrissy, 2000).

Finally, it cannot be excluded that the origin of a parthenogenetic lineage from $P$. fallax was a unique event, a 'macromutation' (White, 1973), which led to apomixis directly from amphimixis (i.e. sexuality).

\section{Ecological implications}

The determination of the identity of the Marmorkrebs is important for considering its invasive potential. In the Everglades and other parts of Florida P.fallax rarely ever exceed $45 \mathrm{~mm}$ carapace length and also its parthenogenetic form becomes only slightly larger (carapace length normally less than $50 \mathrm{~mm}$; Kawai et al., 2009; Pöckl, 2009). Thus, one might think that this should make it a relatively poor candidate for consumption-based aquaculture. Nevertheless, Marmorkrebs has probably been introduced to Madagascar for this reason (Jones et al., 2009; Kawai et al., 2009; Kawai and Takahata, 2010).

Due to its reproduction mode, the parthenogenetic form of $P$. fallax is regarded as a particularly effective invader because only a single individual is able to found a new population (Marten et al., 2004; Jones et al., 2009; Jimenez and Faulkes, 2010). Furthermore, Marmorkrebs is a potential transmitter of the crayfish plague Aphanomyces astaci Schikora, 1906 (Culas, 2003), a highly contagious disease which causes mass mortalities in non-North-American crayfish populations (Oidtmann et al., 1999). Once introduced, these two features make Marmorkrebs a special threat for the indigenous crayfish species.

We already know a number of lifestyle aspects about each of these procambarids from studies in their native wetlands in south Florida (Hendrix and Loftus, 2000; Dorn and Trexler, 2007; Dorn and Volin, 2009). In particular, P. fallax is the smaller of the two species, it is competitively inferior and it grows more slowly (Dorn and Trexler, 2007). P. fallax is a tertiary burrowing species, only burrowing under extreme conditions, and it does not burrow effectively in dense clay or sand substrates (Dorn and Trexler, 2007; Dorn and Volin, 2009). It is generally more abundant in permanent water bodies or in temporary wetlands (drying briefly most years) with lightweight organic soils.

Considering the native distribution of P. fallax in peninsular Florida and southern Georgia (approx. $30.45^{\circ} \mathrm{N}$ latitude) (Hobbs, 1981) the average minimum winter air temperatures fall to around $6^{\circ} \mathrm{C}(\mathrm{My}-$ ers and Ewel, 1990) in the northern part of the range. While populations of the Marmorkrebs seem well established in Madagascar because of its similar climatic conditions, we wonder how well P. fallax could persist in cold winters, for instance in northern or central European lakes or streams where temperatures drop to $\leq 4^{\circ} \mathrm{C}$ under the ice for months. The observation that single specimens are able to survive under an ice cover (Pfeiffer, 2005) and the laboratory results of Seitz et al. (2005) suggest Marmorkrebs has a substantial cold tolerance, but the latter study also showed that their temperature optimum is rather high $\left(18-25^{\circ} \mathrm{C}\right)$. Therefore, more investigations are necessary to evaluate the ability of the parthenogenetic form of $P$. fallax to colonize cold water environments.

\section{Acknowledgements}

P Martin and NJ Dorn contributed equally to this work. We thank Anke Braband and Hong Shen for valuable discussions. The helpful comments of three referees are gratefully acknowledged.

\section{References}

Alwes F, Scholtz G. 2006. Stages and other aspects of the embryology of the parthenogenetic Marmorkrebs (Decapoda, Reptantia, Astacida). Development Genes and Evolution 216: 169-184.

Balitzki-Korte B, Anslinger K, Bartsch C, Rolf B. 2005. Species identification by means of pyrosequencing the mitochondrial 12S rRNA gene. International Journal of Legal Medicine 119: 291-294.

Ball SL. 2002. Population variation and ecological correlates of tychoparthenogenesis in the mayfly, Stenonema femoratum. Biological Journal of the Linnean Society 75: 101-123. 
Brandt JF. 1833. Conspectus monographiae crustaceorum oniscidorum latreillii. Bulletin de la Société Impériale des naturalistes de Moscou 6: 171-193.

Braband A, Kawai T, Scholtz G. 2007. The phylogenetic position of the East Asian freshwater crayfish Cambaroides within the Northern Hemisphere Astacoidea (Crustacea, Decapoda, Astacida) based on molecular data. Journal of Zoological Systematics and Evolutionary Research 44: 17-24.

Buhay JE. 2009. 'COI-like' Sequences are Becoming Problematic in Molecular Systematic and DNA Barcoding Studies. Journal of Crustacean Biology 29: 96-110.

Capelli GM, Capelli JF. 1980. Hybridization between crayfish of the genus Orconectes: morphological evidence (Decapoda, Cambaridae). Crustaceana 39: 121-132.

Castresana J. 2000. Selection of conserved blocks from multiple alignments for their use in phylogenetic analysis. Molecular Biology and Evolution 17: 540-552.

Chu KH, Li CP, Qi J. 2006. Ribosomal RNA as molecular barcodes: a simple correlation analysis without sequence alignment. Bioinformatics 22: 1690-1701.

Clark E. 1936. The freshwater and land crayfishes of Australia. Memoirs of the National Museum of Victoria 10: 5-58.

Clark E. 1941. New species of Australian freshwater and land crayfishes (Family Parastacidae). Memoirs of the National Museum of Victoria 12: 31-40.

Costa FO, deWaard JR, Boutillier J, Ratnasingham S, Dooh RT, Hajibabaei M, Hebert PDN. 2007. Biological identifications through DNA barcodes: the case of the Crustacea. Canadian Journal of Fisheries and Aquatic Sciences 64: 272-295.

Culas A. 2003. Entwicklung einer molekularbiologischen Methode zum Nachweis des Krebspesterregers Aphanomyces astaci SCHIKORA in nordamerikanischen Flusskrebsen (Pacifastacus leniusculus; Orconectes limosus; Procambarus clarkii). Doctoral Thesis. München: Ludwig-MaximiliansUniversität.

Dorn N J, Trexler JC. 2007. Crayfish assemblage shifts in a large drought-prone wetland: the roles of hydrology and competition. Freshwater Biology 52: 2399-2411.

Dorn NJ, Volin JC. 2009. Resistance of crayfish (Procambarus spp.) populations to wetland drying depends on species and substrate. Journal of the North American Benthological Society 28: 766-777.

Enghoff H. 1976. Taxonomic problems in parthenogenetic animals. Zoologica Scripta 5: 103-104.

Faxon W. 1884. Descriptions of new species of Cambarus, to which is added a synonymical list of the known species of Cambarus and Astacus. Proceedings of the American Academy of Arts and Sciences 20: 107-158.

Ferri E, Barbuto M, Bain O, Galimberti A, Uni S, Guerrero R, Ferté H, Bandi C, Martin C, Casiraghi M. 2009. Integrated taxonomy: traditional approach and DNA barcoding for the identification of filarioid worms and related parasites (Nematoda). Frontiers in Zoology 6: 1.

Filipová L, Holdich DM, Lesobre J, Grandjean F, Petrusek A. 2010. Cryptic diversity within the invasive virile crayfish $\mathrm{Or}$ conectes virilis (Hagen, 1870) species complex: new lineages recorded in both native and introduced ranges. Biological Invasions 12: 983-989.

Fitzpatrick JF. Jr. 1978. A new crawfish of the subgenus Girardiella, genus Procambarus from Northwest Arkansas (Decapods, Cambaridae). Proceedings of the Biological Society of Washington 91: 533-538.
Folmer O, Black M, Hoeh, W, Lutz R, Vrijenhoek R. 1994. DNA primers for amplification of mitochondrial cytochrome $\mathrm{c}$ oxidase subunit I from diverse metazoan invertebrates. Molecular Marine Biology and Biotechnology 3: 294-299.

Frost DR, Wright JW. 1988. The taxonomy of uniparental species, with special reference to parthenogenetic Cnemidophorus (Squamata: Teidae). Systematic Zoology 37: 200-209.

Fussey GD. 1984. The distribution of the two forms of the woodlouse Trichoniscus pusillus Brandt (Isopoda: Oniscoidea) in the British Isles: a reassessment of geographic parthenogenesis. Biological Journal of the Linnean Society 23: 309-321.

Girard C. 1852. A revision of the North American Astaci, with observations on their habits and geographical distribution. Proceedings of the Academy of Natural Sciences of Philadelphia 6: 87-91.

Hagen HA. 1870. Monograph of the North American Astacidae. In Illustrated Catalogue of the Museum of Comparative Zoology at Harvard College 3: viii + 109 pages.

Hall TA. 1999. BioEdit: a user-friendly biological sequence alignment editor and analysis program for Windows 95/98/ NT. Nucleic Acids Symposium Series 41: 95-98.

Hebert PD, Cywinska A, Ball SL, deWaard JR. 2003. Biological identifications through DNA barcodes. Proceedings of the Royal Society London B 270: 313-321.

Hendrix AN, Loftus WF. 2000. Distribution and relative abundance of the crayfishes Procambarus alleni (Faxon) and Procambarus fallax (Hagen) in southern Florida. Wetlands 20: 194-199.

Hertig M. 1936. The rickettsia Wolbachia pipientis (gen. et. sp. n) and associated inclusions of the mosquito, Culex pipiens. Parasitology 28: 453-486.

Hobbs HH. 1942. The Crayfishes of Florida. Gainesville: University of Florida Press.

Hobbs HH. Jr. 1972. Crayfish (Astacidae) of North and Middle America. Pp 1 - 173 in: Biota of Freshwater Ecosystems, Identification Manual 9. Washington DC: United States Environmental Protection Agency.

Hobbs HH. Jr. 1979. A new crayfish from the Ouachita River basin in Arkansas (Decapoda: Cambaridae). Proceedings of the Biological Society of Washington 92: 804-811.

Hobbs HH. Jr. 1981. The crayfishes of Georgia. Smithsonian Contributions to Zoology 318: 1-549

Hobbs HH. Jr. 1989. An illustrated checklist of the American crayfishes (Decapoda: Astacidae, Cambaridae, and Parastacidae). Smithsonian Contributions to Zoology 164: $1-236$.

Hobbs HH. Jr. 1990. On the crayfishes (Decapoda: Cambaridae) of the Neches River basin of eastern Texas with the descriptions of three new species. Proceedings of the Biological Society of Washington 103: 573-597.

Holdich DM, Reynolds JD, Souty-Grosset C, Sibley PJ. 2009. A review of the ever increasing threat to European crayfish from non-indigenous crayfish species. Knowledge and Management of Aquatic Ecosystems 394-395: 11.

International Commission on Zoological Nomenclature 1999. International Code of Zoological Nomenclature. London: International Trust for Zoological Nomenclature.

Jimenez SA, Faulkes Z. 2010. Establishment and care of a laboratory colony of parthenogenetic marbled crayfish, Marmorkrebs. Invertebrate Rearing 1: 10-18. 
Jones JP, Rasamy JR, Harvey A, Toon A, Oidtmann B, Randrianarison MH, Raminosoa N, Ravoahangimalala OR. 2009. The perfect invader: a parthenogenetic crayfish poses a new threat to Madagascar's freshwater biodiversity. Biological Invasions 11: 1475-1482.

Kawai T, Takahata M. 2010. The Biology of Freshwater Crayfish. Sapporo: Hokkaido University Press.

Kawai T, Scholtz G, Morioka S, Ramanamandimby F, Lukhaup C, Hanamura Y. 2009. Parthenogenetic alien crayfish (Decapoda: Cambaridae) spreading in Madagascar. Journal of Crustacean Biology 29: 562-567.

Kearney M. 2005. Hybridization, glaciation and geographical parthenogenesis. Trends in Ecology and Evolution 20: 495-502.

Koese B, Vletter W. 2008. Kreeften Nieuwsbrief 1. Stichting EIS Nederland and Bureaus Waardenburg.

Lawrence CS, Morrissy NM. 2000. Hybridization in Australian freshwater crayfish-production of all-male progeny. Journal of the World Aquaculture Society 31: 651-658.

Lukhaup C. 2003. Süßwasserkrebse aus aller Welt. Ettlingen: Dähne Verlag.

Lundmark M, Saura A. 2006. Asexuality alone does not explain the success of clonal forms in insects with geographical parthenogenesis. Hereditas 143: 23-32.

Marten M, Werth C, Marten D. 2004. Der Marmorkrebs (Cambaridae, Decapoda) in Deutschland - ein weiteres Neozoon im Einzugsgebiet des Rheins. Lauterbornia 50: 17-23.

Martin P, Kohlmann K, Scholtz G. 2007. The parthenogenetic Marmorkrebs (marbled crayfish) produces genetically uniform offspring. Naturwissenschaften 94: 843-846.

Martin P, Shen H, Füller G, Scholtz G. 2010. The first record of the parthenogenetic Marmorkrebs (Decapoda, Astacida, Cambaridae) in the wild in Saxony (Germany) raises the question of its actual threat to European freshwater ecosystems. Aquatic Invasions 5, doi: 10.3391 / ai 2010.5.4.

Marzano FN, Scalici M, Chiesa S, Gherardi F, Piccinini A, Gibertini G. 2009. The first record of the marbled crayfish adds further threats to fresh waters in Italy. Aquatic Invasions 4: 401-404.

Mayr E, 2000. The biological species concept. Pp. 17-29 in: Wheeler QD, Maier R, eds., Species Concepts and Phylogenetic Theory. New York: Columbia University Press.

Meier R, Willmann R. 2000. The Hennigian species concept. Pp. 30-43 in: Wheeler QD, Maier R, eds., Species Concepts and Phylogenetic Theory. New York: Columbia University Press.

Munasinghe DHN, Burridge CP, Austin CM. 2004. The systematic of freshwater crayfish of the genus Cherax Erichson (Decapoda: Parastacidae) in eastern Australia: re-examined using nucleotide sequences from 12S rRNA and 16S rRNA genes. Invertebrate Systematics 18: 215-225.

Myers RL, Ewel JJ. 1990. Ecosystems of Florida. Orlando: University of Central Florida Press.

Normark BB. 2003. The evolution of alternative genetic systems in insects. Annual Reviews in Entomology 48: 397-423.

Oidtmann B, Cerenius L, Schmidt I, Hoffman R, Söderhäll K. 1999. Crayfish plague epizootics in Germany - classification of two German isolates of the crayfish plague fungus by random amplification of polymorphic DNA. Diseases of Aquatic Organisms 35: 235-238.

Perry WL, Feder JL, Dwyer G, Lodge DM. 2001a. Hybrid zone dynamics and species replacement between Orconectes crayfishes in a northern Wisconsin lake. Evolution 55: 11531166.
Perry WL, Feder JL, Lodge DM. 2001b. Implications of hybridization between introduced and resident Orconectes crayfishes. Conservation Biology 15: 1656-1666.

Pfeiffer M. 2005. Marmorkrebse überleben im Eis. Fischer \& Teichwirt 2005: 204.

Pöckl M. 2009. Bestimmungsschlüssel und Steckbrief für die in Europa vorkommenden Arten. Pp. 24-33 in: Füreder L, ed., Flusskrebse: Biologie - Ökologie - Gefährdung. Bozen: Folio Verlag.

Rafinesque CS. 1817. Synopsis of four new genera and ten new species of Crustacea, found in the United States. American Monthly Magazine and Critical Revue 2: 40-43.

Reimer RD. 1975. Procambarus (Girardiella) curdi, a new crawfish from Arkansas, Oklahoma, and Texas (Decapoda, Astacidae). Tulane Studies in Zoology and Botany 19:22-25.

Scholtz G, Braband A, Tolley L, Reimann A, Mittmann B, Lukhaup C, Steuerwald F, Vogt G. 2003. Parthenogenesis in an outsider crayfish. Nature 421: 806.

Schubart CD, Huber MGJ. 2006. Genetic comparisons of German populations of the stone crayfish, Austropotamobius torrentium (Crustacea: Astacidae). Bulletin Français de la Pêche et de la Pisciculture 380-381: 1019-1028.

Schwander T, Vuilleumier S, Dubman J, Crespi BJ. 2009. Positive feedback in the transition from sexual reproduction to parthenogenesis. Proceedings of the Royal Society London B 277: 1435-1442.

Seitz R, Vilpoux K, Hopp U, Harzsch S, Maier G, 2005. Ontogeny of the Marmorkrebs (Marbled crayfish): a parthenogenetic crayfish with unknown origin and phylogenetic position. Journal of Experimental Zoology 303A: 393-405.

Sekiné K, Tojo K. 2010. Potential for parthenogenesis of virgin females in a bisexual population of the geographically parthenogenetic mayfly Ephoron shigae (Insecta: Ephemeroptera, Polymitarcyidae). Biological Journal of the Linnean Society 99: 326-334.

Simon J-C, Delmotte F, Rispe C, Crease T. 2003. Phylogenetic relationships between parthenogens and their sexual relatives: the possible routes to parthenogenesis in animals. Biological Journal of the Linnean Society 79: 151-163.

Schikora F. 1906. Die Krebspest. Fischerei-Zeitung 9: 529-532, 549-553, 561-566, 581-583.

Sinclair EA, Fetzner JWJ, Buhay J, Crandall KA. 2004. Proposal to complete a phylogenetic taxonomy and systematic revision for freshwater crayfish (Astacidea). Freshwater Crayfish 14: 21-29.

Souty-Grosset C, Holdich DM, Noël PY, Reynolds JD, Haffner $\mathrm{P}, 2006$. Atlas of Crayfish in Europe. Paris: Museum national d'Histoire naturelle.

Stouthamer R, Breeuwer JA, Hurst GD. 1999. Wolbachia pipientis: microbial manipulator of arthropod reproduction. Annual review of microbiology 53: 71-102.

Sudhaus W, Rehfeld K. 1992. Einführung in die Phylogenetik und Systematik. Stuttgart: Gustav Fischer Verlag.

Suomalainen E, Saura A, Lokki J. 1987. Cytology and Evolution in Parthenogenesis. Boca Raton: CRC Press.

Tamura K, Dudley J, Nei M, Kumar S. 2007. MEGA4: Molecular Evolutionary Genetics Analysis (MEGA) software version 4.0. Molecular Biology and Evolution 24: 1596-1599.

Thacker RW, Hazlett BA, Esman LA, Stafford CP, Keller T. 1993. Color morphs of the crayfish Orconectes virilis. American Midland Naturalist 129: 182-199. 
Thompson JD, Higgins DG, Gibson TJ. 1994. CLUSTAL W: improving the sensitivity of progressive multiple sequence alignment through sequence weighting, position-specific gap penalties and weight matrix choice. Nucleic Acids Research 22: 4673-4680.

Toon A, Finley M, Staples J, Crandall KA. 2009. Decapod phylogenetics and molecular evolution. Pp 15-29 in: Martin JW, Crandall KA, Felder DL, eds., Decapod Crustacean Phylogenetics. Boca Raton: CRC press.

Vandel A. 1928. La parthénogenèse geographique. I. Contribution à l'étude biologique et cytologique de la parthénogenèse naturelle. Bulletin biologique de la France et de la Belgique 62: 164-281.

Vandel A. 1938. Recherchés sur la sexualité des isopodes. III. La déterminisme du sex et de la monogénie chez Trichoniscus (Spiloniscus) provisorus Racovitza. Bulletin biologique de la France et de la Belgique 72: 147-186.

Van Valen L. 1976. Ecological species, multispecies, and oaks. Taxon 25: 233-239.

Vogt G. 2008. The marbled crayfish: New model organism for research on development, epigenetics, and evolutionary biology. Journal of Zoology 276: 1-13.
Vogt G, Tolley L, Scholtz G. 2004. Life stages and reproductive components of the Marmorkrebs (Marbled Crayfish), the first parthenogenetic decapod crustacean. Journal of Morphology 261: 286-311.

Vogt G, Huber M, Thiemann M, van den Boogaart G, Schmitz OJ, Schubart CD. 2008. Production of different phenotypes from the same genotype in the same environment by developmental variation. Journal of Experimental Biology 211: 510-523.

Wheeler QD, Meier R. eds. 2000. Species Concepts and Phylogenetic Theory. New York: Columbia University Press.

White MJD. 1973. Animal cytology and evolution. Cambridge: Cambridge University Press.

Yue GH, Wang GL, Zhu BQ, Wang CM, Zhu ZY, Lo LC. 2008. Discovery of four natural clones in a crayfish species Procambarus clarkii. International Journal of Biological Sciences 4: 279-282.

Received: 25 May 2010

Revised and accepted: 23 August 2010

Published online: 30 September 2010

Editor: J.W. Arntzen 